\title{
ARBUSCULAR MYCORRHIZAL FUNGI INCREASED PLANT GROWTH AND NUTRIENT CONCENTRATIONS OF MILKWOOD TROPICAL TREE SPECIES Alstonia scholaris UNDER GREENHOUSE CONDITIONS
}

\author{
Maman Turjaman ${ }^{1,2}$, Erdy Santoso ${ }^{1}$ and Keitaro Tawaraya ${ }^{3}$
}

\begin{abstract}
The objective of this study was to determine the effect of five arbuscular mycorrhizal (AM) fungi on the early growth of Alstonia scholaris (milkwood) seedlings. The seedlings were inoculated with Glomus clarum Nicholson \& Schenk, Gigaspora decipiens Hall \& Abbott, Glomus sp. ACA Tulasne \& Tulasne, Entrophospora sp. Ames \& Scheneider, and Glomus sp. ZEA Tulasne \& Tulasne, and uninoculated (control) under greenhouse conditions. Percentage of AM colonization, plant growth, survival rate, mycorrhizal dependency $(\mathrm{MD})$, shoot nitrogen $(\mathrm{N})$, phosphorus $(\mathrm{P})$, potassium $(\mathrm{K})$, calcium $(\mathrm{Ca})$, and magnesium $(\mathrm{Mg})$ concentrations were measured after 150 days. Survival rates were higher in the AM-colonized seedlings at 150 days after transplantation than those in the control seedlings. Mycorrhizal Dependency (MD) values were 80, 78, 79, 78 and $78 \%$ in A. scholaris inoculated with G. clarum, G. decipiens, Glomus sp. ACA, Entrophospora sp., and Glomus sp. ZEA, respectively. Shoot $\mathrm{N}, \mathrm{P}, \mathrm{K}, \mathrm{Ca}$ and $\mathrm{Mg}$ content of the seedlings were increased by AM fungi as much as 82-86, 81-86, 81-86, $88-91$ and $85-90 \%$, respectively. The percentage of AM colonization of A. scholaris ranged from 64 to $91 \%$. Colonization by five AM fungi increased plant height, diameter, total fresh weight, total dry weight and total length root. Glomus clarum was more effective in improving nutrient content and plant growth of A. scholaris than G. decipiens, Entrophospora sp., Glomus sp. ZEA and Glomus sp. ACA. Total root length of $A$. scholaris ranged from 1,180 to $1,310 \mathrm{~cm}$. The results suggest that AM fungi can accelerate the establishment of the seedling stocks of $A$. scholaris. This finding would contribute to the effort of establishing $A$. scholaris plantation.
\end{abstract}

Keywords: Glomus sp., Gigaspora decipiens, Entrophospora sp., native mycorrhizal fungi, growth promotion, seedlings, greenhouse.

\section{INTRODUCTION}

The Apocynaceae family is important as they provide valuable timber (Turner, 2001). It consists of 164 genera, and some of these genera, i.e. Tabernaemontana, Secamone, Ochrosia, Dyera, and Alstonia produce timber and nontimber forest products (NTFPs). The genera of Alstonia consists of 40 species, with $A$. angustiloba, A. angustifolia, A. macrophylla, $A$. pneumatophora and $A$. scholaris producing milkwood (Soerianegara and Lemmens, 1994). $A$. scholaris is a medium-sized to large tree, which can grow up to $35 \mathrm{~m}$ in height. Species of $A$. scholaris is common in both primary and secondary lowland evergreen to deciduous rain forest

\footnotetext{
Forest and Nature Conservation Research and Development Center, Jl. Gunung Batu No. 5 Bogor, Indonesia

Corresponding author.E-mail: turjaman@yahoo.com.sg

Faculty of Agriculture, Yamagata University, Tsuruoka 997-8555, Japan
} 
of South Asia, Southeast Asia, Southern China and Northern Australia. Natural regeneration of $A$. scholaris occurs preferentially in open areas at forest edges and in secondary forest, and is considered to be a light-demanding species. Milkwood is suitable for boxes, pencils, crates, coffins, matches, drawing boards, and furniture components. Moreover, valuable latex is also harvested from the stem of $A$. scholaris. The latex can be used for cleaning wounds, traditional medicine and a good-quality chewing gum. In Southeast Asia A. scholaris is a popular medicinal plant. Its root bark is known for its antimalarial properties (Macabeo et al., 2005) and anticancer (Jagetia and Baliga, 2004). However, natural regeneration of $A$. scholaris is scarce, and seedlings found scattered or in groups, making it difficult to produce milkwood.

Deforestation rates on the Indonesian islands of Sumatra and Kalimantan are categorized the highest in the world (Linkie et al., 2004). It is necessary to accelerate reforestation and afforestation in degraded tropical forests and to enhance the commercial value of timber, pulp and NTFPs. A. scholaris is among species that, for its value, should be used in both rehabilitating logged over forest and development of plantation forests. The fast production of high quality seedling stocks in nurseries is valuable for replenishing degraded tropical forests. Furthermore, a lot of soils of tropical forests are infertile and the majority of Indonesian soils are ultisols, which are acid soils. Acid soils are severe environments for plants; high concentrations of $\mathrm{Al}, \mathrm{Mn}$ and $\mathrm{H}$, and low availability of $\mathrm{N}, \mathrm{P}, \mathrm{K}, \mathrm{Ca}$, and $\mathrm{Mg}$ will decrease the chance for many tree species to establish and survive (Postma et al., 2007).

Some studies on the effects of arbuscular mycorrhizal (AM) colonization on plant growth of some tropical trees have been well documented. Arbuscular mycorrhizal fungi increased plant growth of tropical fruit tree species of Parkia biglobosa, Tamarindus indica, and Zizyphus mauritiana at after inoculation (Guisso et al., 1998), Tectona grandis (Rajan et al., 2000), Azadirachta indica (Muthukumar et al., 2001), and Araucaria angustifolia (Zandavalli et al., 2004). However, little is known about AM inoculation on growth of Apocynaceae species in tropical forests. Turjaman et al. (2006) reported that AM fungi increased growth of Dyera polyphylla seedlings, Guadarrama et al. (2004) reported that AM fungi increased growth of Stemmadenia donnell-smithii, Weber et al. (1995) reported that AM fungi increased growth of Adenium obesum, Pachypodium lamerei and Plumeria obtuse. Nevertheless, to the best of our knowledge, there are no reports on the effect of the growth of Alstonia tree species following AM fungal inoculation. The objective of this study was to determine whether five AM fungi, Glomus clarum Nicholson \& Schenk, Gigaspora decipiens Hall \& Abbott, Glomus sp. ACA Tulasne \& Tulasne, Entrophospora sp. Ames \& Scheneider, and Glomus sp. ZEA Tulasne \& Tulasne increase early growth of $A$. scholaris under greenhouse conditions. Isolates of the five AM fungi are native to the peat swamp forests of Central Kalimantan.

\section{MATERIALS AND METHODS}

\section{A. Seed preparation}

Seeds of $A$. scholaris were collected from the arboretum of the Forest and Nature Conservation Research and Development Center (FNCRDC), Bogor, West Java. The seeds were soaked in water for two hours and then surface-sterilized by shaking in $5 \% \mathrm{NaClO}$ solution for $5 \mathrm{~min}$. They were then thoroughly rinsed twice in sterile distilled water. The seeds 
were sown in a plastic flat containing autoclave-sterilized zeolite and grown under a 55\% shading intensity net to control solar radiation. The seeds were allowed to germinate for 21 days after sowing.

\section{B. Soil medium preparation}

Soil used in the experiment was an ultisol collected from the Haurbentes Experimental Forest, Jasinga, West Java ( $\left.6^{\circ} 32^{\prime}-33^{\prime} \mathrm{S}, 108^{\circ} 26^{\prime} \mathrm{E}\right)$ and stored in a greenhouse. It was passed through a five $\mathrm{mm}$ sieve and then mixed with river sand $(3: 1, \mathrm{v} / \mathrm{v})$ to improve drainage. The $\mathrm{pH}\left(\mathrm{H}_{2} \mathrm{O}\right)$ of the soil mixture was 4.8 , available $\mathrm{P}$ (Bray-1) was $0.17 \mathrm{mg} \mathrm{kg}^{-1}$, and total $\mathrm{N}$ (Kjeldahl) was $1.7 \mathrm{mg} \mathrm{kg}^{-1}$. The soil mixture was sterilized at $121^{\circ} \mathrm{C}$ for 30 minutes. Polyethylene pots $\left(15 \mathrm{x} 10 \mathrm{~cm}^{2}\right)$ were filled with $500 \mathrm{~g}$ of sterilized soil mixture.

\section{Arbuscular mycorrhizal fungal inoculum preparation}

Five AM fungi G. clarum, G. decipiens, Glomus sp. ACA, Entrophospora sp. and Glomus sp. ZEA were isolated from peat soil of Kalampangan, Palangkaraya, Central Kalimantan by trap culture. The pot cultures began as single spore cultures. They were propagated in pot cultures of Pueraria javanica. Plastic pots were filled with $175 \mathrm{~g}$ of sterilized zeolite and five $\mathrm{g}$ of AM fungal inoculum in the planting hole. Plastic pots were hung in iron racks $\left(1.5 \mathrm{x} 1 \mathrm{x} 1.5 \mathrm{~m}^{3}\right)$ under greenhouse floor and they were made a distance $15 \mathrm{~cm}$ between pot cultures to avoid contamination. The AM fungi in culture pots were checked as determined by morphological features every two weeks (for three months). A microbial filtrate was not applied to the controls to account for differences from other fungi or bacteria. A preliminary experiment showed that AM fungal inoculum was pure culture and effective without a microbial filtrate application. Two 6-day-old P. javanica seedlings were transplanted into the pots and grown under natural light greenhouse conditions with no temperature and humidity control. After 90 days, spores, external hyphae, and colonized roots of G. clarum, G. decipiens, Glomus sp. ACA, Entrophospora sp. and Glomus sp. ZEA were observed in the zeolite.

\section{Plants inoculation}

One 21-day-old $A$. scholaris seedling was transplanted into the pots containing sterilized soil mixture medium. The AM inoculation was achieved by placing five gram of inoculum of each species 1-3 cm below seedlings. Control seedlings were not mock-inoculated because a preliminary experiment showed that the sterilized inoculum did not affect growth of the seedlings. Seedlings were watered daily with tap water to field capacity. No fertilizer was applied during the course of the experiment. Weeds and pests were removed manually. The seedlings were grown for five months in a greenhouse at the Forest and Nature Conservation Research and Development Center, Bogor, West Java (6 $\left.36^{\prime} \mathrm{S}, 106^{\circ} 45^{\prime} \mathrm{E}\right)$. Temperature varied from 26 to $35^{\circ} \mathrm{C}$, relative humidity was $80-90 \%$ and the photoperiod was about $12 \mathrm{~h}$.

\section{E. Experimental design}

The experiment consisted of six treatments of $A$. scholaris seedlings (a) control (no inoculation), (b) inoculation with G. clarum, (c) inoculation with G. decipiens, (c) inoculation with G. decipiens; (d) inoculation with Glomus sp. ACA; (e) inoculation with Entrophospora sp.; 
(f) inoculation with Glomus sp. ZEA. There were ten replications per treatment. Shoot height and stem diameter at one $\mathrm{cm}$ from the soil surface were measured five months after transplantation. After harvest, shoots and roots were separated. They were oven-dried at $70^{\circ}$ $\mathrm{C}$ for $72 \mathrm{~h}$ before weighing. Ground shoots were digested with $\mathrm{H}_{2} \mathrm{SO}_{4}$ and $\mathrm{H}_{2} \mathrm{O}_{2}$ solution $(3: 1$, $\mathrm{v} / \mathrm{v}) . \mathrm{N}$ and $\mathrm{P}$ concentration in the digested solution were determined by the semi-micro Kjeldahl method and vanadomolybdate-yellow assay (Olsen and Sommers, 1982), respectively. $\mathrm{K}, \mathrm{Ca}$ and $\mathrm{Mg}$ were determined by means of an atomic absorption spectrophotometer (Heffernan, 1985). An additional 30 seedlings each of A. scholaris uninoculated or inoculated with $G$. clarum or G. decipiens or Glomus sp. ACA or Entrophospora sp. or Glomus sp. ZEA were grown under the same conditions as those of the seedlings in the above experiment. Numbers of viable seedlings were counted 5 months after transplanting. Survival rate was calculated as follows:

\section{Survival rate $(\%)=($ number of viable seedlings/number of initial seedlings $) \times 100$}

Roots of $A$. scholaris were washed gently over a two $\mathrm{mm}$ sieve under running tap water to separate them from soil particles. The roots were cleared in $100 \mathrm{~g} \mathrm{l}^{-1} \mathrm{KOH}$ for $1 \mathrm{~h}$, acidified with diluted $\mathrm{HCl}$ and stained with $500 \mathrm{mg} \mathrm{l}^{-1}$ trypan blue in lactoglycerol (Brundrett et al., 1996). Roots were destained with 50\% glycerol and $301-\mathrm{cm}$ segments were viewed under a compound microscope at x200 magnification. Percentage of AM colonization was estimated using the gridline intersect method (Giovannetti and Mosse, 1980). Mycorrhizal dependency (MD) was calculated according to Plenchette et al. (1983): MD (\%) = (dry weight of mycorrhizal plant-dry weight of non mycorrhizal plant) / dry weight of mycorrhizal plant x 100. Root length were measured by gridline millimeter block.

Data were statistically analyzed using analysis of variance with the statistical software StatView 5.0 (Abacus Concepts). Comparison of means was done using the least significant difference (LSD) method at the $5 \%$ probability level where the F-value was significant.

\section{RESULTS AND DISCUSSION}

The roots of A. scholaris were colonized by G. clarum, G. decipiens, Glomus sp. ACA, Entrophospora sp. and Glomus sp. ZEA 150 months after transplantation under greenhouse conditions (Table 1.). There was no difference in percentage of colonization among $G$. clarum, G. decipiens, Glomus sp. ACA, Entrophospora sp. and Glomus sp. ZEA. The control seedlings of $A$. scholaris were colonized by indigenous AM fungi. AM colonization by $G$. clarum, G. decipiens, Glomus sp. ACA, Entrophospora sp. and Glomus sp. ZEA increased plant height, stem diameter, total fresh and dry weight of $A$. scholaris 5 months after transplantation (Table 1.) and ready for planting in the field. 
Table 1. Arbuscular mycorrhizal (AM) colonization, shoot and root growth of A. scholaris inoculated with or without AM fungi

\begin{tabular}{|c|c|c|c|c|c|}
\hline \multirow[b]{2}{*}{ Treatment } & \multicolumn{3}{|c|}{ Plant growth } & & \multirow{2}{*}{$\begin{array}{c}\text { AM } \\
\text { Colonization } \\
(\%)^{*}\end{array}$} \\
\hline & $\begin{array}{l}\text { Height } \\
(\mathrm{cm})^{*}\end{array}$ & $\begin{array}{c}\text { Stem } \\
\text { diameter } \\
(\mathrm{mm})^{*} \\
\end{array}$ & $\begin{array}{c}\text { Total fresh } \\
\text { weight } \\
\text { (g/plant)* }\end{array}$ & $\begin{array}{l}\text { Total dry } \\
\text { weight } \\
\text { (g/plant)* }\end{array}$ & \\
\hline No inoculation & $16.1 \mathrm{a}$ & $3.9 \mathrm{a}$ & $5.3 \mathrm{a}$ & $1.1 \mathrm{a}$ & $5 \mathrm{a}$ \\
\hline G. clarum & $33.1 \mathrm{~b}$ & $6.5 b$ & $20.6 b$ & $5.6 \mathrm{~b}$ & $64 b$ \\
\hline G. decipiens & $34.1 \mathrm{~b}$ & $6.9 \mathrm{~b}$ & $18.7 \mathrm{~b}$ & $5.1 b$ & $79 \mathrm{~b}$ \\
\hline Glomus sp. ACA & $32.8 \mathrm{~b}$ & $6.8 \mathrm{~b}$ & $19.7 b$ & $5.2 \mathrm{~b}$ & $74 \mathrm{~b}$ \\
\hline Entrophospora sp. & $36.1 \mathrm{~b}$ & $6.6 \mathrm{~b}$ & $19.2 \mathrm{~b}$ & $4.9 \mathrm{~b}$ & $79 b$ \\
\hline Glomusp. ZEA & $32.5 b$ & $6.5 b$ & $20.3 b$ & $5.0 \mathrm{~b}$ & $91 b$ \\
\hline
\end{tabular}

*Values with the same letter are not significantly different $(\mathrm{P}<0.05)$

This study clearly demonstrates that inoculation of five AM fungi increased the early growth and nutrient content of $A$. scholaris five months under greenhouse conditions. This species is an important tree species in tropical forest of Asia because it produces milkwood. Within the same family of Aponynaceae, the growth of AM seedlings of $A$. scholaris is better than AM seedlings of Dyera polyphylla (Turjaman et al., 2006). The AM seedlings of A. scholaris can be planted in the field after five months in greenhouse or nursery. Shoot height, stem diameter, and total dry weight were also increased by inoculation of AM fungi. These parameters can determine the value of $A$. scholaris as the milkwood. The improvement of early growth of these species would increase production of the milkwood. Moreover, inoculation of AM fungi would be useful for production of $A$. scholaris because this species is often scarce and found scattered or in groups in natural tropical forests.

Nutrient concentrations were higher in shoots of $A$. scholaris inoculated with G. clarum, G. decipiens, Glomus sp. ACA, Entrophospora sp., and Glomus sp. ZEA than those of control seedlings (Table 2.). The inoculation of $A$. scholaris by five AM fungi also increased their shoot $\mathrm{N}, \mathrm{P}, \mathrm{K}, \mathrm{Ca}$ and $\mathrm{Mg}$ content. Arbuscular mycorrhizal colonization by five AM fungi increased shoot N, P, K, Ca and Mg content of $A$. scholaris. There was no difference in shoot N, P, K, Ca and $\mathrm{Mg}$ content of $A$. scholaris among G. clarum, G. decipiens, Glomus sp. ACA, Entrophospora sp., and Glomus sp. ZEA. Shoot nutrient concentrations and content of $A$. scholaris were higher in the seedlings inoculated with G. clarum than G. decipiens, Glomus sp. ACA, Entrophospora sp., and Glomus sp. ZEA treatments. Shoot nutrient concentrations of $A$. scholaris were higher in the AM seedlings than in the control seedlings, indicating that in the absence of AM associations, A. scholaris was not capable to absorb enough $\mathrm{N}, \mathrm{P}, \mathrm{K}, \mathrm{Ca}$ and $\mathrm{Mg}$ from the soil and keep adequate levels in their tissues. Arbuscular mycorhizal seedling inoculated by G. clarum increased their shoot $\mathrm{N}, \mathrm{P}, \mathrm{K}, \mathrm{Ca}$ and $\mathrm{Mg}$ concentrations by 27, 33, 30, 55, and 47\%, respectively. Similar results, was reported by Zandavalli et al. (2004) that Araucaria angustifolia 
inoculated by G. clarum increased their shoot N, P, K concentrations, except for shoot Ca and $\mathrm{Mg}$ concentrations of inoculated plants were not different with control seedlings. Soil bases such as $\mathrm{Mg}$ and $\mathrm{Ca}$ have a role in root colonization and sporulation of AM fungi (Jarstfer et al., 1998). Moreover, high $\mathrm{Mg}$ /low Ca shoot concentrations induced premature root senescence, which may have disturbed the AM association process, indicating the importance of Ca for the maintenance of a functioning AM symbiosis. In addition, Cuenca and Azcón (1994) reported that AM fungi G. etunicatum was not only increasing the N, P, Ca, Mg and Zn uptake of tropical tree Erythrina poeppigiana in the presence of $\mathrm{NO}_{3}$ fertilizer, but also $\mathrm{P}$ and $\mathrm{Mg}$ in the presence of $\mathrm{NH}_{4}^{+}$applications. The AM colonization by G. clarum, G. decipiens, Glomus sp. ACA, Entrophospora sp. and Glomus sp. ZEA increased also the nutrient content. Shoot height, stem diameter, fresh and dry weight were also increased by inoculating those five AM fungi. Increases of these parameters may lead to increase benefit from the milkwood and medicinal plant of $A$. scholaris. Furthermore, AM fungal inoculation induces healthy and vigorous growth of seedlings, which would be helpful to reforestation and afforestation activities. AM colonization also increased nutrient content of $\mathrm{N}, \mathrm{P}, \mathrm{K}, \mathrm{Ca}$, and $\mathrm{Mg}$ of $A$. scholaris. Shoot $\mathrm{N}, \mathrm{P}$, $\mathrm{K}$, Ca, and $\mathrm{Mg}$ content of the AM inoculated seedlings were increased by $82-86,81-86,81-86$, $88-91$, and $85-90 \%$, respectively. Fertilizers are generally of benefit to the tree, not the site, and measurable permanent site improvement is only likely if the amount of nutrient applied is large in relation to the soil fertility (Miller, 1981). Fertilization has been generally applied to A. scholaris in nursery on the commercial scale. Fertilization had the most dramatic effect and caused a decrease of AM colonization and thereafter reduces growth improvement by AM fungi (Titus and Lepš, 2000). Effective AM fungal inoculum could be produced on the commercial scale and at low cost production, therefore application of AM fungi can minimize fertilization without diminish AM growth enhancement of $A$. scholaris.

Table 2. Shoot nutrient concentration and content of $A$. scholaris inoculated with or without AM fungi

\begin{tabular}{|c|c|c|c|c|c|c|c|c|c|c|}
\hline \multirow{3}{*}{ Treatment } & \multicolumn{5}{|c|}{ Shoot Nutrient Concentration } & \multicolumn{5}{|c|}{ Shoot Nutrient Content } \\
\hline & $\mathrm{N}$ & $\mathrm{P}$ & $\mathrm{K}$ & $\mathrm{Ca}$ & $\mathrm{Mg}$ & $\mathrm{N}$ & $\mathrm{P}$ & $\mathrm{K}$ & $\mathrm{Ca}$ & $\mathrm{Mg}$ \\
\hline & \multicolumn{10}{|c|}{$(\mathrm{mg} / \mathrm{g})(\mathrm{mg} / \mathrm{g})(\mathrm{mg} / \mathrm{g})$} \\
\hline Control & $6.7 \mathrm{a}$ & $1.4 \mathrm{a}$ & $5.5 \mathrm{a}$ & $2.9 \mathrm{a}$ & $1.7 \mathrm{a}$ & $4.5 \mathrm{a}$ & $1.0 \mathrm{a}$ & $3.7 \mathrm{a}$ & $1.9 \mathrm{a}$ & $1.1 \mathrm{a}$ \\
\hline G. clarum & $9.2 \mathrm{c}$ & $2.1 \mathrm{c}$ & $7.9 \mathrm{c}$ & $6.4 \mathrm{c}$ & 3.2 & $32.1 \mathrm{~b}$ & $7.4 \mathrm{~b}$ & $27.6 \mathrm{~b}$ & $22.3 b$ & $11.1 \mathrm{~b}$ \\
\hline G. decipiens & $8.8 \mathrm{c}$ & $1.9 \mathrm{~b}$ & $7.7 \mathrm{c}$ & $6.0 \mathrm{c}$ & $2.9 \mathrm{c}$ & $27.4 \mathrm{~b}$ & $6.1 \mathrm{~b}$ & $23.9 \mathrm{~b}$ & $18.8 \mathrm{~b}$ & $9.1 \mathrm{~b}$ \\
\hline Glomusp. ACA & $7.8 \mathrm{~b}$ & $1.8 \mathrm{~b}$ & $6.6 \mathrm{~b}$ & $5.7 \mathrm{c}$ & $2.3 \mathrm{~b}$ & $25.0 \mathrm{~b}$ & $5.7 \mathrm{~b}$ & $21.3 b$ & $18.4 \mathrm{~b}$ & $7.4 \mathrm{~b}$ \\
\hline Entrophospora sp. & $7.9 \mathrm{~b}$ & $1.7 \mathrm{~b}$ & $6.3 \mathrm{~b}$ & $5.0 \mathrm{~b}$ & $2.3 \mathrm{~b}$ & $24.8 \mathrm{~b}$ & $5.3 \mathrm{~b}$ & $19.6 \mathrm{~b}$ & $15.5 b$ & $7.3 \mathrm{~b}$ \\
\hline Glomus sp. ZEA & $8.6 \mathrm{c}$ & $1.8 \mathrm{~b}$ & $7.0 \mathrm{~b}$ & $6.0 \mathrm{c}$ & $2.9 \mathrm{c}$ & $26.3 \mathrm{~b}$ & $5.4 \mathrm{~b}$ & $21.2 \mathrm{~b}$ & $18.5 b$ & $8.8 \mathrm{~b}$ \\
\hline
\end{tabular}

*Values with the same letter are not significantly different $(\mathrm{P}<0.05)$ 
Entrophospora sp. and Glomus sp. ZEA increased the survival rates of $A$. scholaris 5 months after transplantation under greenhouse conditions. The survival rates of $A$. scholaris inoculated with G. clarum (93\%), G. decipiens (100\%), Glomus sp. ACA (100\%), Entrophospora sp. $(100 \%)$ and Glomus sp. ZEA(100\%) were higher than control seedlings (80\%). The $A$. scholaris seedlings inoculated with G. clarum, G. decipiens, Glomus sp. ACA, Entrophospora sp. and Glomus sp. ZEA were not different in survival rates. The survival rate of $A$. scholaris seedlings is an evaluation decisive factor of success in reforestation and afforestation programs. These results also have a number implication for forest plantation management of $A$. scholaris. This species can be planted as monoculture or agroforestry systems because $A$. scholaris is a fast growing species and almost similar growth performance with plantation forest industry species like Acacia, Eucalyptus and Gmelina. In South Sumatra (Indonesia), a forest plantation company has a sharing with local farmers to establish forest plantation industry for supplying raw materials of pencil. They provide $A$. scholaris to farmers who are planting and maintaining the seedlings in their forest gardens. The forest plantation company or farmers may get yield and increase production of $A$. scholaris inoculated by AM fungi.

Arbuscular mycorhizal colonization by five AM fungi increased total root length, total first roots, total second roots and total third roots of $A$. scholaris (Table 3.). There was no difference in total root length, total first roots, total second roots and total third roots of $A$. scholaris among G. clarum, G. decipiens, Glomus sp. ACA, Entrophospora sp. and Glomus sp. ZEA. There was no difference in total main root of $A$. scholaris between five AM fungi and control seedlings. The AM increased total root length of $A$. scholaris. Even though colonization by AM fungi characteristically results in more numerous lateral roots in the hosts, these are much shorter than in non-colonized root systems (Berta et al., 1993). The AM seedlings can increase the length and fineness of their roots or the length and density of their root hairs in the response to P deficiency (Trolove et al., 2003). AM seedlings are able to obtain more nutrients from nutrient-deficient soils than are control seedlings because hyphae exploit a greater volume of soil than roots alone (Entry et al., 2002). AM enhances plant acquisition of nutrients by increasing the absorptive surface area of the uptake system. P uptake is most likely the best described process in the AM associations, with the fungi supplying host plants with $P$ in exchange for carbon (Smith and Read, 1997). In a greenhouse study, Inoculation of AM fungi increased soil compaction reduced root length, AM formation, root dry weight, P content and shoot growth on Cajanus cajan L. (Yano et al., 1998), Trifolium subterraneum L. (Nadian et al., 1997), Trifolium pratense L. (Li et al., 1997). The proportion of root length colonized by the fungus increases with decreasing nutrient availability (Graham et al., 1997).

Table 3. Total length roots of $A$. scholaris inoculated with or without AM fungi

\begin{tabular}{lcccccc}
\hline \multirow{2}{*}{ Treatment } & \multicolumn{4}{c}{ Root length $(\mathrm{cm})$} & \multirow{2}{*}{$\begin{array}{c}\text { Total root length } \\
(\mathrm{cm})\end{array}$} \\
\cline { 2 - 5 } & main root & 1 st root & 2nd root & 3rd root & $208.1 \mathrm{a}$ \\
Control & $15.4 \mathrm{a}$ & $88.6 \mathrm{a}$ & 79 & $\mathrm{a}$ & $25.1 \mathrm{a}$ & $1181.8 \mathrm{~b}$ \\
G. clarum & $16.9 \mathrm{a}$ & $410.8 \mathrm{~b}$ & 524 & $\mathrm{~b}$ & $230.1 \mathrm{~b}$ & $1277.1 \mathrm{~b}$ \\
G. decipiens & $17.5 \mathrm{a}$ & $440.6 \mathrm{~b}$ & $646.8 \mathrm{~b}$ & $172.2 \mathrm{~b}$ & $1241.2 \mathrm{~b}$ \\
Glomus sp. ACA & $18.6 \mathrm{a}$ & $384.6 \mathrm{~b}$ & $588.5 \mathrm{~b}$ & $249.5 \mathrm{~b}$ & $1149.7 \mathrm{~b}$ \\
Entrophospora sp. & $16.6 \mathrm{a}$ & $363.6 \mathrm{~b}$ & $528.8 \mathrm{~b}$ & $240.7 \mathrm{~b}$ & $1309.7 \mathrm{~b}$ \\
Glomus sp. ZEA & $15.1 \mathrm{a}$ & $378.7 \mathrm{~b}$ & $664.3 \mathrm{~b}$ & $251.6 \mathrm{~b}$ & \\
\hline
\end{tabular}

$*$ Values with the same letter are not significantly different $(\mathrm{P}<0.05)$. 
For a given fungus, Mycorrhizal Dependency (MD) values were 80, 78, 79, 78 and 78\% in A. scholaris inoculated with G. clarum, G. decipiens, Glomus sp. ACA, Entrophospora sp. and Glomus sp. ZEA, respectively. The MD in acid soil was higher $(>75 \%)$ in $A$. scholaris inoculated with AM fungi. A. scholaris was very highly dependent according to the MD categories defined by Habte and Manajunath (1991). A. scholaris responded to the AM colonization more largely. The MD proposed that AM inoculation would be valuable in production of vigorous seedlings in the nursery which might establish in the field conditions and might be more resistant to drought stress, nutrient deficiency and pathogenic infection (Wilson et al., 1991; Ghosh and Verma, 2006). Moreover, Cáceres and Cuenca (2006) reported that MD has other functions in two tropical species from Venezuela Clusia minorand Clusia multiflora in two soils with different $\mathrm{pH}$. Both tree species were found to be highly dependent on AM fungi for their growth in acidic soil, and there was an inverse relationship between dependency of the species and the soil phosphorus content.

\section{CONCLUSIONS}

This study is the first report of which we are aware concerning the inoculation of AM fungi on the growth of milkwood tropical tree species $A$. scholaris. Colonization by five AM fungi increased shoot nutrient content, plant growth, and survival rates of $A$. scholaris seedlings 5 months after transplantation under greenhouse conditions. Glomus clarum was more effective in improving nutrient content and plant growth of $A$. scholaris than $G$. decipiens, Entrophospora sp., Glomus sp. ZEA, and Glomus sp. ACA. Field trials with AM fungal inoculation are required to monitor the growth and survival rates of $A$. scholaris. Inoculation techniques may be adopted by a large scale nursery jointly with reforestation and afforestation programs, thereby aiding in the increase of the milkwood production of such tropical tree species as $A$. scholaris. These results suggested that AM fungi increased the establishment of the planting stocks of $A$. scholaris, thereby sustaining the production of $\operatorname{milkwood} A$. scholaris.

\section{REFERENCES}

Berta, G., A. Fusconi, and A.Trotta. 1993. VA mycorrhizal infection and the morphology and function of root systems. Environmental and Experimental Botany 33:159-173.

Brundrett, M., N. Bougher, B. Dell , T. Grove, and N. Malajczuk. 1996. Working with mycorrhizas in forestry and agriculture. ACIAR Monograph 32, Canberra.

Cáceres, A. and G. Cuenca. 2006. Contrasting response of seedlings of two tropical species Clusia minor and Clusia multiflora to mycorrhizal inoculation in two soils with different pH. Trees 20: 593-600.

Cuenca, G. and R. Azcón. 1994. Effects of ammonium and nitrate on the growth of vesicular Arbuscular mycorrhizal Erythrina poeppigiana O.I. Cook seedlings. Biology and Fertility of Soils 18: 249-254. 
Entry, J.A., P.T. Rygiewicz, L.S.Watrud, and P.K. Donnelly. 2002. Influence of adverse soil conditions on the formation and function of arbuscular mycorrhizas. Advances Environmental Research 7:123-138.

Ghosh, S. and N.K.Verma. 2006. Growth and mycorrhizal dependency of Acacia mangium Willd. Inoculated with three vesicular arbuscular mycorrhizal fungi in lateritic soil. New Forests 31: 75-81.

Giovannetti, M. and B. Mosse. 1980. An evaluation of techniques for measuring vesiculararbuscular mycorrhizal infection in roots. New Phytology 84: 489-500.

Graham, J.H., L.W. Duncan, and D.M. Eissenstat. 1997. Carbohydrate allocation patterns in citrus genotypes as affected by phosphorus nutrition, mycorrhizal colonization and mycorrhizal dependency. New Phytology 135: 335-343.

Guadarrama, P., J.Álvarez-Sánchez and O. Briones. 2004. Seedling growth of two pioneer tropical tree species in competition: The role of arbuscular mycorrhizae. Euphytica 138: 113-121.

Guisso, T., A.M. Bâ, J-M. Ouadba, S. Guinko, and R. Duponnois. 1998. Responses of Parkia biglobosa (Jacq.) Benth, Tamarindus indica L. and Zizyphus mauritiana Lam. to arbuscular mycorrhizal fungi in a phosphorus-deficient sandy soil. Biology and Fertility of Soils 26: 194-198.

Habte, M. and A. Manajunath. 1991. Categories of vesicular-arbuscular mycorrhizal dependency of host species. Mycorrhiza 1:3-12.

Heffernan, B.J. 1985. A Handbook of methods of inorganic chemical analysis for forest soils, foliage and water. CSIRO Division of Forest Research, Canberra. 281pp.

Jarstfer, A.G., P. Farmer-Koppenol, and D.M. Sylvia. 1998. Tissue magnesium and calcium affect arbuscular mycorrhiza development and fungal reproduction. Mycorrhiza 7: 237-242.

Jagetia, G.C. and M.S. Baliga. 2004. Effect of Alstonia scholaris in enhancing the anticancer activity of berberine in the Ehrlic ascites carcinoma-bearing mice. Journal of Medicinal Food 7: 235-244.

Li, X.L., E. George, and H. Marschner. 1997. Extension of the phosphorus depletion zone in VA-mycorrhizal white clover in a calcareous soil. Plant Soil 136: 41-48.

Linkie, M., R.J. Smith and N. Leader-Williams. 2004. Mapping and predicting deforestation patterns in the lowlands of Sumatra. Biodiversity and Conservation 13: 1809-1818.

Macabeo, A.P.G., K. Krohn, D. Gehle, R.W. Read, J.J. Brophy, G.A. Cordell, S.G. Franzblau, and A.M. Aguinaldo. 2005. Indole alkaloids from the leaves of Philippine Alstonia scholaris. Phytochemistry 66:1158-1162.

Miller, H.G. 1981. Forest fertilization: some guiding concepts. Forestry 54:157-167. 
Muthukumar, T., K. Udaiyan, and V. Rajeshkannan. 2001. Response of neem (Azadirachta indica A. Juss) to indigenous arbuscular mycorrhizal fungi, phosphate-solubilizing and asymbiotic nitrogen-fixing bacteria under tropical nursery conditions. Biology and Fertility of Soils 34:417-426.

Nadian, H., S.E. Smith, A.M. Alston, and R.S. Murray. 1997. Effects of soil compaction on plant growth, phosphorus uptake and morphological characteristics of vesicular arbuscular mycorrhizal colonization of Trifolium subterraneum. New Phytology 135: 303311.

Olsen, S.R. and L.E. Sommers. 1982. Phosphorus. In: A.L. Page (Editor). Methods of Soil Analysis. Part 2 Chemical and Microbiological Properties. American Society of Agronomy, Madison. pp. 403-430.

Postma, J.W.M., P.A. Olsson, and U. Falkengren-Grerup. 2007. Root colonization by arbuscular mycorrhizal, fine endophytic and dark septate fungi across a $\mathrm{pH}$ gradient in acid beech forests. Soil Biology and Biochemistry 39: 400-408.

Plenchette, C., J.A. Fortin, and V. Furlan. 1983. Growth responses of several plant species to mycorrhizae in a soil of moderate P-fertility. I. Mycorrhizal dependency under field conditions. Plant Soil 70: 199209.

Rajan, S.K., B.J.D. Reddy and D.J. Bagyaraj. 2000. Screening of arbuscular mycorrhizal fungi for their symbiotic efficiency with Tectona grandis. Forest Ecology and Management 126: 91-95.

Soerianegara, I. and R.H.M.J. Lemmens (Eds). 1994. Timber trees : Major commercial timbers. Plant Resources of South-East Asia No. 5 (1). Prosea, Bogor, Indonesia.

Smith, S.E. and D.J. Read. 1997. Mycorrhizal Symbiosis. Academic Press, Inc.: San Diego, CA.

Titus, J.H. and J. Lepš. 2000. The response of arbuscular mycorrhizae to fertilization, mowing, and removal of dominant species in a diverse oligotrophic wet meadow. American Journal of Botany 87:392-401.

Trolove, S.N., M.J. Hedley, G.J.D. Kirk, N.S. Bolan, and P. Loganathan. 2003. Progress in selected area of rhizosphere research on $\mathrm{P}$ acquisition. Australian Journal of Soil Research 41:471-499.

Turjaman, M., Y. Tamai, E. Santoso, M. Osaki, and K. Tawaraya. 2006. Arbuscular mycorrhizal fungi increased early growth of two nontimber forest product species Dyera polyphylla and Aquilaria filaria under greenhouse conditions. Mycorrhiza 16: 459-464.

Turner, I.M. 2001. The ecology of tree in the tropical rain forest. Cambridge Tropical Biology Series. Cambridge University Press.

Weber, H.C., A. Klahr, and M. MarronHeimbuch. 1995. Anatomical structures of the VA mycorrhiza in the Apocynaceae (Gentianales). Botanica Acta 108: 525-534. 
Wilson, J., R.C. Munro, K. Ingleby, P.A. Mason, J. Jefwa, P.N. Muthoka, J. McP. Dick, and R.R.B. Leakey. 1991. Tree establishment in semiarid lands of Kenya role of mycorrhizal inoculation and water-retaining polymer. Forest Ecology Management 45: 153-163.

Yano, K., A.Yamaguchi, M. Iijima, and Y. Kono. 1998. Arbuscular mycorrhizal formation in undisturbed soil counteracts compacted soil stress for pigion pea. Applied Soil Ecology 10: $95-102$.

Zandavalli, R.B., L.R. Dillenburg, and P.V.D. de Souza. 2004. Growth responses of Araucaria angustifolia (Araucariaceae) to inoculation with the mycorrhizal fungus Glomus clarum. Applied Soil Ecology 25:245-255. 